\title{
Evaluation of Phenolic Content and Free Radical Scavenging Activity of Indonesia Wild Honey Collected from Seven Different Regions
}

\author{
Y. Riswahyuli ${ }^{1,3}$, Abdul Rohman ${ }^{2}$, Francis M. C. S. Setyabudi ${ }^{1} \&$ Sri Raharjo $^{1}$ \\ ${ }^{1}$ Department of Food and Agricultural Product Technology, Faculty of Agricultural Technology, Universitas \\ Gadjah Mada, Jl. Flora 1, Bulaksumur, Sleman, Yogyakarta, Indonesia \\ ${ }^{2}$ Faculty of Pharmacy, Universitas Gadjah Mada, Yogyakarta, Indonesia \\ ${ }^{3}$ National Agency of Drug and Food Control (BPOM RI), Jakarta, Indonesia \\ Correspondence: Sri Raharjo, Department of Food and Agricultural Product Technology, Faculty of Agricultural \\ Technology, Universitas Gadjah Mada, Jl. Flora 1, Bulaksumur, Sleman, Yogyakarta, Indonesia. Tel: \\ 62-274-589-797.
}

$\begin{array}{ll}\text { Received: September 12, } 2019 & \text { Accepted: October 20, } 2019 \quad \text { Online Published: October 29, } 2019 \\ \text { doi:10.5539/jfr.v8n6p94 } & \text { URL: https://doi.org/10.5539/jfr.v8n6p94 }\end{array}$

\begin{abstract}
Several wild honey samples collected from seven different regions in Indonesia were investigated to determine their total phenolic content, flavonoid content, and free radical scavenging activity by analyzing the 1,1-diphenyl-2-picrylhydrazyl (DDPH) radical and phenolic profile. Rutin, (+)-catechin, ferulic acid, and galangin were found to be the major phenolic compounds of Indonesia wild honey. The total phenolic content significantly correlated with the total flavonoid content $(\mathrm{p}=0.000)$ and the percentage of DPPH radical scavenging activity $(\mathrm{p}=0.000)$. Results indicated that there are different polyphenol profiles among the different regions.
\end{abstract}

Keywords: wild honey, antioxidant, polyphenolic, flavonoid

\section{Introduction}

Honey is a natural food produced by honey bees using flower nectar or tree and plant exudates. Recently, honey has become extremely popular because of its potential beneficial effects for human health. It has been used as a common traditional drug since ancient times for treating burns, gastrointestinal problems, asthma, infection and wounds, skin ulcers, and cataracts and other eye diseases (Osés, et al., 2016; Ferreira, et al., 2009). The beneficial effects of honey can be partly attributed to its antibacterial and antioxidant activities. Studies have shown that honey exhibits activity against oxidation reactions in food such as enzymatic browning, lipid oxidation, and food deterioration(Ardehali, et al., 2017; Ferreira, et al., 2009; Antony, et al., 2000; Chen, et al., 2000).

The antioxidant activity of honey is due to a combination of compounds such as phenolic acids, flavonoids, ascorbic acid, carotenoids, enzymes, amino acids, and products derived from the Maillard reaction (Gül \& Pehlivan, 2018; Moniruzzaman, et al. 2014, Khalil, et al. 2011, and Gheldof, et al. 2002).Recently, there has been a significant increase in research on the characterization of natural polyphenols especially their identification and quantification (Pyrzynska, \& Biesaga, 2009). This research direction has been largely oriented toward identifying a promising marker compound (Kus, et al., 2014; Kaškoniene, \& Venskutonis, 2010), and such studies have reported more than 150 polyphenol compounds from honey bee products (Ferreira, et al., 2009).

The concentration and the class of antioxidants are highly dependent on the floral source and the total capacity of the antioxidants, which comprises a combination of activity of compounds found in honey (Gheldof, et al., 2002). Earlier studies have demonstrated that the capacity of antioxidants in honey obtained from various flower sources significantly correlated with its phenolic and flavonoid contents and the origin of the flower (Alvarez-Suarez, et al., 2009; Baltrušaityte, et al., 2007; Gheldof, et al., 2002; Anklam, 1998). One study showed that the important components, including phenolic derivatives, present inplant nectar are transferred to honey (Idris, et al., 2011). The primary factor responsible for the antioxidant activity of honey is the substituent group present in its phenolic components, e.g., hydroxyl, methyl, acyl, or glycosyl groups (Gašic et al., 2014). 
Regarding the flavonoids present in honey, previous studies have reported that pinobanksin, pinocembrin, quercetin, chrysin, galangin, luteolin, and kaempferol are the major ones, whereas luteolin, quercetin, 8-methoxykaempferol, is or hamnetin, kaempferol, and galangin are present in small concentrations in Manuka honey (Alvarez-Suarez, et al., 2014; Chan, et al., 2013; Kaškonienand Veskutonis, 2010). This characterization of polyphenols was useful for differentiating the source of honey and could be used as a botanical marker (Spilioti, et al., 2014; Alvarez-Suarez, et al 2014; Anklam, 1998; Tomas-Barberan, et al., 1993). Caffeic acid and $p$-coumaric acid found in chestnut honey and protocatechuic acid found in conifer tree honey have been used as flower markers in some previous studies (Haroun, et al., 2012; Tomas-Barberan, 2001).

Today, several methods are used to explore the antioxidant activity of honey, such as determination of active oxygen species, radical scavenging activity (RSA) (Alvarez-Suarez, et al., 2009; Gheldof, et al., 2005; Meda, et al., 2005; Gheldof, et al., 2002; Nagai, T, et al., 2001),measurement of the inhibition of lipid peroxidation by enzymatic or nonenzymatic reactions (Nagai, et al., 2001; Chen, et al., 2000), and ferric reducing antioxidant power assay (Bertoncelj, et al., 2007; Aljadi \& Kamarudin,2004).

Chromatographic fingerprinting is an efficient and widely used method for determining the content of polyphenols or antioxidant compounds (Zhao, et al., 2016; Sun et al., 2014; Kuś, et al., 2014). Solid-phase extraction techniques have been successfully applied,followed by the identification of the compounds by capillary electrophoresis (CE), gas chromatography, or high-performance liquid chromatography (HPLC).The use ofdiode array detector (DAD) and mass spectrometry (MS) demonstrated greater effectiveness, especially withHPLC in cases of flavonoids and with GC in cases of phenolic acids (Alvarez-Suarez, et al., 2009). Several researchers have demonstrated that HPLC with DAD and GC-MS are useful for the characterization of honey from plant sources (Kus, et al., 2014; Soria, et al., 2009).Till date, only a few studies have reported about the determination of total phenolic content (TPC), antioxidant activity, and the phenolic profile of honey in Indonesia (Chayati, 2008; Kartika \& Bertoni, 2014; Kustiawan 2014). Therefore, we conducted this study to determine the TPC, the total flavonoid content (TFC), the (RSA) (DPPH), and the phenolic profiling by HPLC DAD using wild honey collected from seven different regions or islands in Indonesia.

\section{Material and Method}

\subsection{Honey Samples}

Indonesia wild honey (IWH) samples were collected between 2016 and 2018 from seven different regions in seven different islands in Indonesia. The regions wereas follows: Bangka Belitung, Sulawesi, Kalimantan, Sumatra, West Nusa Tenggara, East Nusa Tenggara, and Java (Figure 1). Their authenticity and freshness wereassured by collecting them directly from the forest areas, local beekeepers under the Indonesia Wild Honey Association, and/or from well-traced suppliers. The samples were collected in sealed glasscontainers and kept in dark conditions.

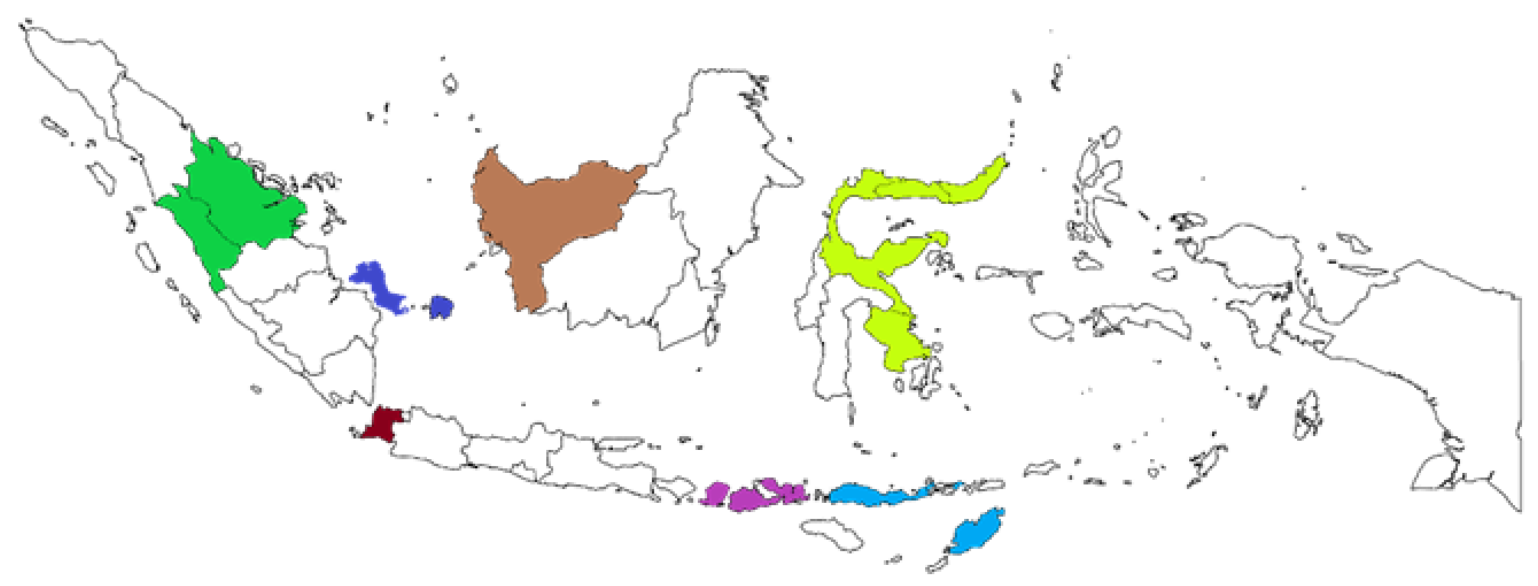

(9) Vemaps.com

Figure 1. Sampling area for Wild Honey ( $\square=$ Sumatera island (Riau\& Jambi ) $\square=$ Bangka \& Belitung Island $\square=$ Java (Banten province) $\square=$ Kalimantan Island (West Kalimantan Province $\square=$ Sulawesi Island

(South Sulawesi, Central Sulawesi, Gorontalo \& North Sulawesi) $\square=$ West Nusa Tenggara (Sumbawa Province) $\quad$ =East Nusa Tenggara (Kupang, Timor Tengah Selatan, Flores Timur \&Sikka) 


\subsection{Analysis of TPC}

TPC was determined using the Folin-Ciocalteu method at a wavelength of $750 \mathrm{~nm}$ with gallic acid as the standard (Ferreira, et al 2009; Socha, et al., 2007; Prior, et al., 2005; Singleton, et al., 1999; Singleton, et al., $1965)$. About $0.5 \mathrm{~mL}$ of honey solution $(100 \mathrm{mg} / \mathrm{mL})$ that was previously homogenized was added to $0.3 \mathrm{~mL}$ of $10 \%$ Folin-Ciocalteu reagent. Then, $2 \mathrm{~mL}$ of $15 \%$ sodium carbonate solution $\left(\mathrm{Na}_{2} \mathrm{CO}_{3}\right)$ was added after $6 \mathrm{~min}$ and the volume was made up to $5 \mathrm{~mL}$ using distilled water. This solution was incubated for $20 \mathrm{~min}$ in the dark before measuring using a spectrophotometer. A calibration curve was plotted at a predetermined concentration of $0-300 \mathrm{mg} / \mathrm{L}$, and the results were expressed in milligrams of gallic acid equivalent ( $\mathrm{mg} / \mathrm{kg} \mathrm{GAE}$ ).

\subsection{Analysis of TFC}

The TFC was measured using the method developed by Zhishen et al. (1999). Briefly, $2 \mathrm{~mL}$ of honey solution in water $(1 \mathrm{~g} / 4 \mathrm{~mL})$ was mixed with $0.3 \mathrm{~mL}$ of $5 \% \mathrm{NaNO}_{2}(\mathrm{w} / \mathrm{v})$. After $5 \mathrm{~min}, 0.3 \mathrm{~mL}$ of $10 \% \mathrm{w} / \mathrm{v} \mathrm{AlCl}_{3}$ was added to the solution, followed by the addition of $2 \mathrm{mLofNaOH}$ and then $10 \mathrm{~mL}$ of distilled water after $6 \mathrm{~min}$. The absorbance of the solution was read in a Thermo Scientific Genesys $10 \mathrm{~S} \mathrm{UV-Vis} \mathrm{spectrophotometerat} 425 \mathrm{~nm}$. A calibration curve was plotted with quercetinas the standard at a concentration range of $0-8 \mathrm{mg} / \mathrm{L}$. The results were expressed as milligrams of quercetine quivalent (QEQ) per $100 \mathrm{~g}$ of honey.

\subsection{Radical Scavenging Activity}

The antioxidant activity of all honey samples was measured using the scavenging activity for the radical DPPH as developed by Meda et al (2005). The homogenized sample was weighed and dissolved in methanol (150 $\mathrm{mg} / \mathrm{mL})$. The honey solution $(0.075 \mathrm{~mL})$ was mixed with the DPPH reagent solution $(0.025 \mathrm{mg} / \mathrm{mL})$ and left for $15 \mathrm{~min}$ at room temperature in the dark condition. The absorbance of the mixture was measured at $517 \mathrm{~nm}$ against methanol blank. The RSAwas expressed as \% inhibition according to the following equation:

$$
\% \text { inhibition }=\frac{\text { Blank absorbance }- \text { Control absorbance })}{\text { Blank absorbance }} \times 100 \%
$$

\subsection{Analysis of Phenolic Compound Profile}

\subsubsection{Sample Extraction}

The homogenized sample $(0.5 \mathrm{~g})$ was dissolved in $10 \mathrm{~mL}$ of acidified deionized water $(\mathrm{pH} 3.5)$ and inserted into the SPE column Bond Elut octadecyl C18 (500 mg) from Agilent Technology (Santa Clara, CA, USA)whichwas previously conditioned using $4 \mathrm{~mL}$ of methanol and $2 \mathrm{~mL}$ of deionized water. Subsequently, the column was washed with $6 \mathrm{~mL}$ of deionized water ( $\mathrm{pH} 3.5)$ and the desirable fraction was eluted by passing $2 \mathrm{~mL}$ of absolute methanol. Before injecting into the HPLC system, the sample extracts were filtered through a $0.45-\mu \mathrm{m}$ membrane filter (Millipore) (Gašić et al., 2014; Beretta et al., 2005).

\subsubsection{Preparation of Polyphenolic Standards}

All standards were prepared using methanol to make $500 \mathrm{mg} / \mathrm{L}$ of standard stock solution. Working standards were prepared by diluting the stock solution with methanol to serial concentrations of $0.10,0.25,0.50,0.75$, and $1.00 \mathrm{mg} / \mathrm{L}$. A calibration curve was drawn by plotting the analyte peak areas against the serial concentration of the working standard solutions. The calibration curve was considered to have good linearity if the $\mathrm{R}^{2}$ values were $>0.99$. The standards of ferulic acid, $p$-coumaric acid, vanillic acid, gallic acid, quercetin, tricine,4-hydroxybenzoic acid, (+)-catechin, syringaldehyde, rutin trihydrate, chrysin, galangin, epigallocatechin, and 3,4-dihydroxy benzaldehydewere purchased from Sigma-Aldrich (St. Louis, Missouri, USA). Methanol was of HPLC grade purchased from Merck. All solutions were filtered and degassed before use.

\subsubsection{HPLC Analysis}

The honey samples were analyzed using a Shimadzu liquid chromatographic system equipped with binary pumps LC20-A, degasser DGU-20A5, autosampler SIL-20AC, photodiode array detector set to a wavelength of $280 \mathrm{~nm}$, and a Shimadzu Shim pack GIST column $(5 \mu \mathrm{m}, 4.6 \times 15 \mathrm{~mm}$.). The mobile phase consisted of a combination of water-acetic acid (phase A) and methanol-acetic acid (phase B). The system was run with a gradient elution with the following conditions: time $0.02 \mathrm{~min}, 18.3 \%$ phase $\mathrm{B}$; time $10 \mathrm{~min}, 100 \%$ phase $\mathrm{B}$; time $13.1 \mathrm{~min}, 18.3 \%$ phase B. The flow rate was set to $1 \mathrm{~mL} / \mathrm{min}$ with an injection volume of $20 \mu \mathrm{L}$.

\subsection{Statistical Analysis}

Statistical analyses were conducted using the computer programs SPSS 24.0 Statistics software (SPSS Inc., 2016), Minitab® 18.1 (State College, Pennsylvania, USA) and Microsoft Excel 2016 (Microsoft Corp.). Data were presented as mean \pm S.D. The Pearson correlation was calculated to determine the relationship between the 
phenolic acid content and antioxidant properties. The level of significance was set at $\mathrm{p}<0.01$.

\section{Results and Discussion}

\subsection{TPC and TFC}

The TPC (mg/kg of honey) exhibited significant variations among the various samples of IWH (Table 1), which might be due to the differences in the botanical and regional origin (Tahir, et al 2017; Mamary et al., 2002). The TPC of the IWH samples varied from $188.03(\mathrm{mg} / \mathrm{kg}$ GAE) in Kalimantan to 467.84 (mg/kg GAE) inEast Nusa Tenggara (Table 1$)$ with standard linearity $\left(\mathrm{R}^{2}=0.9990\right)$. This value was still higher than previously reported, namely, lime honey $(83.7 \mathrm{mg} / \mathrm{kg})$, Slovenia honey $(44.8 \mathrm{mg} / \mathrm{kg})$, and honey from Burkina Faso $(74.38 \mathrm{mg} / \mathrm{kg})$ (Moniruzzaman, et al., 2014;Bertoncelj, et al., 2007;Meda, et al 2005).

In this study, the TFC was evaluated using an aluminum chloride reagent, which was specific to only flavones and flavonols, so that the test results would provide a lower estimation of the number of flavonoids because they ignored the flavanone compounds (Meda, et al., 2015). The TFC of the IWH samples ranged from $0.81 \mathrm{mg}$ $\mathrm{QEQ} / 100$ gin honey from Kalimantan to $3.09 \mathrm{mg} \mathrm{QEQ} / 100 \mathrm{~g}$ in honey from Sumatra (Table 1), made by calibration curve of quercetin with $\mathrm{R}^{2}=0.9999$. These results were closely similar to the values of other honey samples in the world such as those from Bangladesh(2.57 mg QEQ/100 g) (Moniruzzaman, et al., 2011), Burkina Faso(2.57 $\pm 2.09 \mathrm{mg}$ QEQ/100 g), Europe (0.5-2 mg QEQ/100 g) (Amiot et al., 1989; Martos et al., 2000), Czech (1.9-15.74 mg QEQ/100g) (Vit, et al., 2008), andFrance ( $<1 \mathrm{mg} Q E Q / 100 \mathrm{~g}$ ). The most significant positive linear correlation was observed between the phenolic and flavonoid parameters $(r=0.533, \mathrm{p}=0,000$, Table 2$)$. It has been reported that honey samples with a higher polyphenol content produce high levels of flavonoids (Moniruzzaman, 2014, Khalil, 2012).

Table 1. Mean and standard deviation of antioxidant parameters

\begin{tabular}{|c|c|c|c|c|c|c|c|c|}
\hline \multirow{3}{*}{$\begin{array}{l}\text { Antioxidant } \\
\text { Parameters }\end{array}$} & & \multicolumn{7}{|c|}{ Origin of Indonesia Wild Honey } \\
\hline & & Bangka & Sulawesi & Kalimantan & Sumatra & West Nusa & East Nusa & Java \\
\hline & & Belitung & & & & Tenggara & Tenggara & \\
\hline \multirow[t]{2}{*}{ TPC* } & mean & $254.92 \pm$ & $423.17 \pm$ & $188.03 \pm$ & $422.9528 \pm$ & $467.84 \pm$ & $343.15 \pm$ & $250.96 \pm$ \\
\hline & $\pm \mathrm{SD}$ & $83.26^{\mathrm{ac}}$ & $55.45^{\mathrm{b}}$ & $6.74^{\mathrm{ca}}$ & $64.95^{\mathrm{d}}$ & $45.66^{\mathrm{e}}$ & $84.18^{f}$ & $66,46^{\mathrm{g}}$ \\
\hline TFC** & Mean \pm SD & $1.09 \pm 0.38^{\mathrm{a}}$ & $2.57 \pm 1.35^{\mathrm{bd}}$ & $0.81 \pm 0.21^{\mathrm{c}}$ & $3.09 \pm 0.79^{\mathrm{db}}$ & $2,22 \pm 0.57^{\mathrm{e}}$ & $1.46 \pm 0.29^{\mathrm{fg}}$ & $1,13 \pm 0.64^{\mathrm{gf}}$ \\
\hline$\%$ Inhibition & Mean \pm SD & $28.23 \pm 6,68^{\mathrm{a}}$ & $80.74 \pm 19.00^{\text {bd }}$ & $49.24 \pm 5.15^{\mathrm{ceg}}$ & $69.85 \pm 9.76^{\mathrm{db}}$ & $51.24 \pm 10.61^{\mathrm{ecg}}$ & $68.65 \pm 12.23^{f}$ & $50.42 \pm 4.6^{\mathrm{gec}}$ \\
\hline Number of samples & & 7 & 12 & 10 & 41 & 29 & 30 & 20 \\
\hline
\end{tabular}

*Total Phenolic Content (mg of gallic acid equivalent (GAE) per kg)

**Total Flavonoid Content (mg quercetin(QEQ)/100 g)

\subsection{Radical Scavenging Activity}

The results of RSA are summarized in Table 1 . The percentage inhibitory activity of IWH ranged from $28.23 \%$ to $80.74 \%$. The highest mean value was found in honey collected from Sulawesi, whereas the lowest was observed in honey collected from Bangka Belitung. These results were higher to those of Portuguese honey collected from several vegetation sources such as rosemary $(4.5 \%-59.3 \%)$, orange $(8.8 \%-23.2 \%)$, thyme $(35.8 \%-47.3 \%)$, and eucalyptus (27.7\%) (Alves, et al., 2013). Other studies have reported that Lithuania honey has an RSA value of 43.0\%-95.7\% (Baltrušaityte, et al., 2005),dark honey samples have a DPPH inhibitory value of69.2\%, and light honey samples have an inhibitory value of $37 \%$ (Estevinho et al.,2008). Similarly, rhododendron honey samples showed inhibitory values between $2.30 \%$ and $90.73 \%$ (Silici et al., 2010).

A positive correlation was observed among the RSA, TPC, and TFC of the honey samples, with a Pearson coefficient $<0.001$. The TPC showed a weak correlation with the antioxidant activity, whereas the TFC exhibited a moderate correlation with RSA (Table 2). These results were similar to those of previous studies that reported that the phenolic acid and flavonoid contents and the antioxidant potential of honey were significantly correlated, which was influenced by the origin of the sample (Jaromír, et al 2010; Beretta, et al., 2005). This correlation indicates that the phenolic compounds have an effect on the antioxidant potential. 
Table 2. Correlation of Total Phenolic, Total Flavonoid, and \% Inhibition

\begin{tabular}{llllll}
\hline & & Total Phenolic & Total Flavonoid & $\%$ Inhibition \\
\cline { 2 - 5 } Total Phenolic & Pearson Correlation & 1 & $.533^{* *}$ & $.336^{* *}$ \\
& Sig. (2-tailed) & & .000 & .000 \\
& $\mathrm{~N}$ & 145 & 145 & 138 \\
\multirow{5}{*}{ Total Flavonoid } & Pearson Correlation & $.533^{* *}$ & 1 & $.504^{* *}$ \\
& Sig. (2-tailed) & .000 & & .000 \\
& $\mathrm{~N}$ & 145 & 149 & 142 \\
& \% Inhibition & Pearson Correlation & $.336^{* *}$ & $.504^{* *}$ & 1 \\
& Sig. (2-tailed) & .000 & .000 & \\
& $\mathrm{~N}$ & 138 & 142 & 142 \\
\hline
\end{tabular}

**. Correlation is significant at the 0.01 level (2-tailed).

\subsection{Profile of Phenolic Compounds}

In general, the analysis procedure for determining a single phenolic compound needs the sample preparation step intended for extraction from the honey matrix, followed by separation, identification, and quantification steps. The extraction step generally involves SPE or solvent extraction using various solvents. Separation is generally done by HPLC or CE because of the presence of electroactive phenolic hydroxyl groups with simple oxidation potential. Some authors had conducted SPE procedures to extract phenolic components from honey (Aljadi \& Kamarudin, 2004). Quantitation was done on 13 phenolic compounds, but only 10 of them were able to produce linear equations with $\mathrm{R}^{2}=0.99$ (Table 3 ). Other flavonoids such as syringaldehyde and rutin, although they were detected, could not produce linear equations that met the requirements for quantification.

Results of the phenolic profile are represented in Table 4 and Figure 1. Gallic acid, (+)-catechin, quercetin, epigallocatechin, pinocembrin, 4-hydroxybenzoic acid, chrysin, galangin, vanillic acid, and ferulic acid were detected in all types of honey samples collected from various regions, whereas3,4-dihydroxy benzaldehyde was detected only in the honey samples collected from Sumatra, East Nusa Tenggara, and Java. Syringaldehyde was detected only in Sumatra and Java honey samples, andrutin was found only in Sumatra and East Nusa Tenggara honey samples. An earlier study reported that pinocembrin, pinobanksin, chrysin, and luteolin represented approximately $61 \%$ of the flavonoid content of Manuka honey (Chan, et al., 2013). In this study, the levels of each phenolic compound in each region varied significantly, which may be due to variation in the types of vegetation or multiflora. The dominant phenolic compound found in honey collected from Bangka Belitung was galangin $(75.43-103.88 \mathrm{mg} / \mathrm{kg}$ ), which was also detected in honey collected from Sulawesi but at a lower level $(14.68-26.52 \mathrm{mg} / \mathrm{kg})$. Epigallocatechin was the most dominant phenolic compound in honey collected from Kalimantan (3.027-34.617 mg/kg), whereas catechin was the dominant phenolic compound found in honey collected from Java. Ferulic acid was the most dominant phenolic compound in honey collected from West Nusa Tenggara (51.64-286.43 mg/kg), whereas the honey samples collected from East Nusa Tenggara and Sumatra showeda lower concentration of this compound.Polyphenolic content in several honey were than their TPC and TFC. This condition allows the exploration of other dominant phenolic compounds, which could not be identified in these experiments. It has been reported that the variation in the composition of phenolic compounds depends on the floral source transfer to the nectar, climate and other environmental factors, bee variety, and the processing technologies, handling, and storage (Kaskonienè and Venskutonis, 2010; Bertoncelj, et al., 2007). This variation in the profile of phenolic compounds was considered to be responsible for their diverse response in protecting against oxidative reactions. This compound could also be used as an indicator in studies analysing the flower and geographic origins of honey (Idris, Mariod, \& Hamad, 2011; Alvarez-Suarez, et al., 2009). 
Table 3. HPLC data for polyphenol standards at $\lambda 280 \mathrm{~nm}$

\begin{tabular}{llll}
\hline Polyphenols & $\mathrm{T}_{\mathrm{R}}(\mathrm{min})$ & Regression Equation & $\mathrm{R}^{2}$ \\
\hline Gallic acid & 2.74 & $\mathrm{Y}=45617.3{ }^{*} \mathrm{x}-10073.4$ & 0.99 \\
(+)-catechin & 5.82 & $\mathrm{Y}=10181.8^{*} \mathrm{x}-2078.88$ & 0.99 \\
3,4-dihydroxy benzaldehyde & 6.06 & $\mathrm{Y}=55287.5{ }^{*} \mathrm{x}-10670.5$ & 0.99 \\
Quercetin & 6.41 & $\mathrm{Y}=29263.2 * \mathrm{x}-2762.52$ & 0.99 \\
Epigallocatechin & 6.74 & $\mathrm{Y}=26279.1{ }^{*} \mathrm{x}-2731.40$ & 0.99 \\
Pinocembrin & 7.06 & $\mathrm{Y}=34401.9^{*} \mathrm{x}-6223.43$ & 0.99 \\
4-hydroxybenzoic acid & 7.46 & $\mathrm{Y}=31344.3{ }^{*} \mathrm{x}-6814.47$ & 0.99 \\
Chrysin & 7.78 & $\mathrm{Y}=132703^{*} \mathrm{x}-5297.36$ & 0.99 \\
Galangin & 8.02 & $\mathrm{Y}=2500.68^{*} \mathrm{x}+2802.56$ & 0.99 \\
Vanillic acid & 9.03 & $\mathrm{Y}=21305.2 * \mathrm{x}-8083.04$ & 0.99 \\
Ferulic acid & 9.93 & $\mathrm{Y}=1138.20 * \mathrm{x}-239.447$ & 0.99 \\
\hline
\end{tabular}

Table 4. Quantification data of phenolic compounds in Indonesia wild honey

\begin{tabular}{llllllll}
\hline Polyphenols $(\mu \mathrm{g} / \mathrm{mL})$ & $\begin{array}{l}\text { Bangka } \\
\text { Belitung }\end{array}$ & Sulawesi & Kalimantan & Sumatra & $\begin{array}{l}\text { West } \\
\text { Tenggara }\end{array}$ & $\begin{array}{l}\text { Eust } \\
\text { Tenggara }\end{array}$ & $\begin{array}{l}\text { Nusa } \\
\text { Java }\end{array}$ \\
\hline Gallic acid & $0.25-4.92$ & $0.25-0.78$ & $0.29-1.57$ & $0.41-4.0$ & $0.36-6.09$ & $0.27-4.43$ & $0.27-5.67$ \\
(+)-catechin & $42.59-69.52$ & $1.69-17.09$ & $0.84-7.14$ & $4.71-29.00$ & $6.28-22.86$ & $0.60-16.40$ & $1.02-27.77$ \\
3,4 dihydroxy benzaldehyde & ND & ND & ND & $0.19-9.61$ & Not detected & $0.20-0.19$ & $0.21-0.81$ \\
Quercetin & $6.57-17.10$ & $0.14-23.86$ & $0.78-6.58$ & $0.31-4.76$ & $1.10-7.11$ & $0.41-2.22$ & $0.09-2.02$ \\
Epigallocatechin & $6.64-65.81$ & $1.25-48.09$ & $3.03-34.62$ & $0.24-5.83$ & $4.69-16.64$ & $0.23-8.62$ & $0.098-3.99$ \\
Pinocembrin & $2.10-9.36$ & $0.24-4.86$ & $1.15-6.16$ & $1.51-15.20$ & $1.46-22.39$ & $0.48-3.70$ & $0.34-2.42$ \\
4-hydroxybenzoic acid & $1.56-3.66$ & $0.27-0.57$ & $5.65-8.82$ & $0.25-9.66$ & $1.18-4.75$ & $0.30-4.09$ & $0.25-15.79$ \\
Chrysin & $8.56-8.75$ & $0.16-2.72$ & $0.37-2.63$ & $1.35-12.19$ & $0.23-2.29$ & $0.57-3.73$ & $0.32-3.57$ \\
Galangin & $75.43-103.88$ & $14.68-26.53$ & $0.492-23.22$ & $0.64-20.38$ & $0.88-15.54$ & $1.13-51.27$ & $0.45-44.67$ \\
Vanillic acid & $9.05-33.52$ & $0.44-0.45$ & $0.52-4.89$ & $0.47-1.86$ & $2.02-13.50$ & $0.57-9.77$ & $0.44-18.56$ \\
Syringaldehyde & ND & ND & ND & Detected & ND & ND & Detected \\
Ferulic acid & $1.58-2.47$ & $1.59-43.39$ & $0.78-34.77$ & $10.22-41.71$ & $51.64-286.43$ & $1.01-108.73$ & $2.82-11.45$ \\
Rutin & ND & ND & ND & Detected & ND & Detected & ND \\
\hline
\end{tabular}

\section{ND: Not Detected}

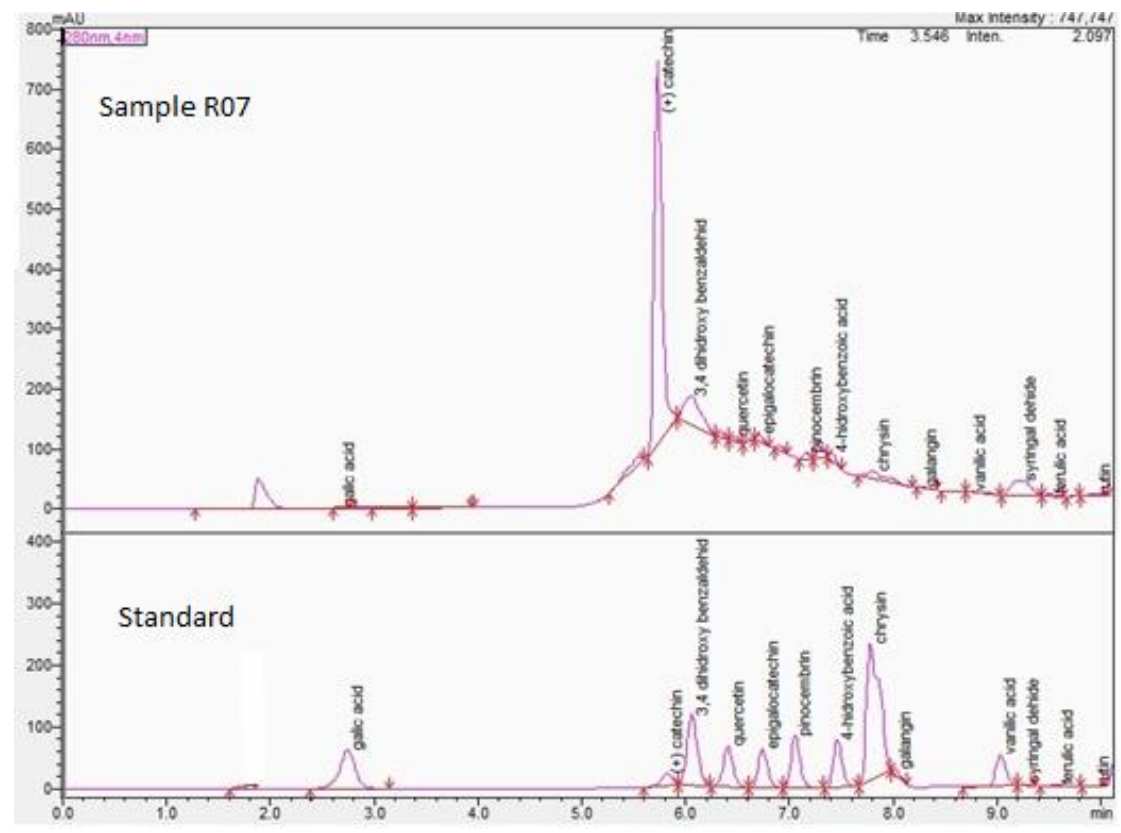

Figure 2.HPLC Chromatogram for Sample from Sumatra region and polyphenolic standard 


\section{Conclusion}

This study demonstrated that a correlation exists among the TPC, TFC, and RSA values of the IWH samples. The phenolic profile varied significantly at both intra- or inter-region levels, which could be due to the variation in the planttype as a source of nectar. The dominant phenolic compounds in the IWH samples were (+)-catechin, ferulic acid, and galangin, whereas some compounds were found only in honey collected from certain regions; for example, 3, 4-dihydroxy benzaldehyde was detected only in honey collected from Sumatra, East Nusa Tenggara, and Java; syringaldehyde was found in honey collected from Sumatra and Java; and rutin was detected in honey samples collected from Sumatra and East Nusa Tenggara.

\section{Acknowledgements}

The authors would like to thank National Agency of Drug and Food Control (NADFC) Republic of Indonesia/ Badan Pengawas Obat dan Makanan (BPOM) for their financial support. Hermanto of Indonesia Wild Honey Network (IWHN)/Jaringan Madu Indonesia (JMHI), Budi Aulia and Afri Yondra of WWF Indonesia, Riau Program, Bahrizon of Riau beekeepers, Eman Sulaeman of Koperasi Hanjuang, Banten, Novemris Tefa and Asbanu Nicodemus of Gunung Mutis National Park, Anis Hayong of Rumadu, Flores, Jalisman of Waslit, North Luwu, Tri Astuti Rahmawati from BPOM provincial office in Bangka Belitung, and Kristiorini Dwi Nursanti for supplying honey samples.

\section{References}

Aljadi, A. M., \& Kamaruddin, M. Y. (2004). Evaluation of the phenolic contents and antioxidant capacities of two Malaysian floral honeys. Food Chem., 85, 513-518. https://doi.org/10.1016/S0308-8146(02)00596-4

Alvarez-Suarez, J., Gasparrini, M., Forbes-Hernández, T., Mazzoni, L., \& Giampieri, F. (2014). The Composition and Biological Activity of Honey: A Focus on Manuka Honey. Foods, 3(3), 420-432. https://doi.org/10.3390/foods3030420

Alvarez-Suarez, J. M., Tulipani, S., Romandini, S., Vidal, A., \& Battino, M. (2009). Methodological aspects about determination of phenolic compounds and in vitro evaluation of antioxidant capacity in the honey: A review. Current Analytical Chemistry, 5(4), 293-302. https://doi.org/10.2174/157341109789077768

Alves, A., Ramos, A., Gonçalves, M. M., Bernardo, M., \& Mendes, B. (2013). Antioxidant activity, quality parameters and mineral content of Portuguese monofloral honeys. Journal of Food Composition and Analysis, 30(2), 130-138. https://doi.org/10.1016/j.jfca.2013.02.009

Amoit, M. J., Aubert S., Gonnet, M., \& Tacchini, M. (1989). The phenolic compounds in honeys: preliminary study upon identification and family quantification. Apidologie, 20, 115-125. https://doi.org/10.1051/apido:19890202

Anklam, E. (1998). A review of the analytical methods to determine the geographical and botanical origin of honey. Food Chemistry, 63(4), 549-562. https://doi.org/10.1016/S0308-8146(98)00057-0

Anthony, S. M., Rieck, J. R., \&Dawson, P. L. (2000). Effect of dry honey on oxidation in turkey breast meat. Poult. Sci., 79, 1846-1850. https://doi.org/10.1093/ps/79.12.1846

Ardehali, P., Asadi, F., Javan, A., Jahantigh, M., \& Aminzare, M. (2017). Application of honey to reduce oxidation in soybean oil. Journal of Food Quality and Hazards Control, 4(3), 79-84.

Baltrušaityte, V., Venskutonis, P. R., \& Čeksteryte, V. (2007). Radical scavenging activity of different floral origin honey and beebread phenolic extracts. Food Chemistry, 101(2), 502-514. https://doi.org/10.1016/j.foodchem.2006.02.007

Beretta, G., Granata, P., Ferrero, M., Orioli, M., \& Maffei Facino, R. (2005). Standardization of antioxidant properties of honey by combination of spectrophotometric / fluorimetric assays and chemometrics of spectrophotometric / fluorimetric assays and chemometrics. Analytica Chimica Acta, 533, 185-191. https://doi.org/10.1016/j.aca.2004.11.010

Bertoncelj, J., Doberšek, U., Jamnik, M., \& Golob, T. (2007). Evaluation of the phenolic content, antioxidant activity and colour of Slovenian honey. Food Chemistry, 105(2), 822-828. https://doi.org/10.1016/j.foodchem.2007.01.060

Chan, C. W., Deadman, B. J., Manley-Harris, M., Wilkins, A. L., Alber, D. G., \& Harry, E. (2013). Analysis of the flavonoid component of bioactive New Zealand mānuka (Leptospermum scoparium) honey and the isolation, characterisation and synthesis of an unusual pyrrole. Food Chemistry, 141(3), 1772-1781.

https://doi.org/10.1016/j.foodchem.2013.04.092 
Chayati, I. (2008). Sifat fisikokimia madu monoflora dari daerah istimewa yogyakarta dan jawa tengah. Agritech, 28(1), 9-14.

Chen, L., Mehta, A., Berenbaum, M., Zangerl, A. R., \& Engeseth, N. J. (2000). Honeys from different floral sources as inhibitors of enzymatic browning in fruit and vegetable homogenates. J. Agric. Food Chem., 48, 4997-5000. https://doi.org/10.1021/jf000373j

Ciappini, M. C., \& Stoppani, F. S. (2014). Determination of antioxidant capacity, flavonoids, and total phenolic content in eucalyptus and clover honeys. Journal of Apicultural Science, 58(1), 103-111. https://doi.org/10.2478/jas-2014-0010

Escriche, I., Kadar, M., Juan-Borrás, M., \& Domenech, E. (2014). Suitability of antioxidant capacity, flavonoids and phenolic acids for floral authentication of honey. Impact of industrial thermal treatment. Food Chemistry, 142, 135-143. https://doi.org/10.1016/j.foodchem.2013.07.033

Estevinho, L., Pereira, A. P., Moreira, L., Dias, L. G., \& Pereira, E. (2008). Antioxidant and antimicrobial effects of phenolic compounds extracts of Northeast Portugal honey. Food and Chemical Toxicology, 46(12), 3774-3779. https://doi.org/10.1016/j.fct.2008.09.062

Ferreres, F., Tomas-Barberan, F. A., Gil, M. I., \& Tomas, F. (1991). HPLC technique for flavonoid analysis in honey. J. Sci. Food Agric., 56, 49-56. https://doi.org/10.1002/jsfa.2740560106

Gašic', U., Dabic, D., Kec, S., Trifkovic, J., Milojkovic, D., Tešic, Z., \& Natic, M. (2014). Phenolic profile and antioxidant activity of Serbian polyfloral honeys. Food Chemistry, 145, 599-607. https://doi.org/10.1016/j.foodchem.2013.08.088

Gheldof, N., \& Engeseth, N. J. (2002). Antioxidant capacity of honeys from various floral sources based on the determination of oxygen radical absorbance capacity and inhibition of in vitro lipoprotein oxidation in human serum samples. Journal of Agricultural and Food Chemistry, 50(10), 3050-3055. https://doi.org/10.1021/jf0114637

Gheldof, N., Xiao-Hong, W., \& Engeseth, N. (2002). Identification and quantification of antioxidant components of honeys from various floral sources. J. Agric. Food Chem., 50, 5870-5877. https://doi.org/10.1021/jf0256135

Gül, A., \& Pehlivan, T. (2018). Antioxidant activities of some monofloral honey types produced across Turkey. Saudi Journal of Biological Sciences, 25, 1056-1065. https://doi.org/10.1016/j.sjbs.2018.02.011

Haroun, M. I., Poyrazoglu, E. S., Konar, N., \& Artik, N. (2012). Phenolic acids and flavonoids profiles ofsome Turkish honeydew and floral honeys. J Food Technol, 10, 39-45. https://doi.org/10.3923/jftech.2012.39.45

Kartika, S. R., \& Bertoni, R. (2014). Kajian Manfaat Madu Hutan Anggota JMHI terhadap Penyakit Kanker dan Anti Aging. Jaringan Madu Hutan Indonesia Scientific Report.

Kaškonien, V., \& Venskutonis, P. R., (2010). Floral Markers in Honey of Various Botanical and Geographic Origins : A Review. Comprehensive Reviews in Food Science and Food Safety, 9. https://doi.org/10.1111/j.1541-4337.2010.00130.x

Khalil, M. I. N., Alam, M., Moniruzzaman, S. A., \& Gan, S. H. (2011). Phenolic acid composition and antioxidant properties of Malaysian honeys. Journal of Food Science, 76(6), C921-C928, 2011. https://doi.org/10.1111/j.1750-3841.2011.02282.x

Kustiawan, P. M., Puthong, S., Arung, E. T., \& Chanchao, C. (2014). In vitro cytotoxicity of Indonesian stingless bee products against human cancer cell lines. Asian Pac. J. Trop. Biomed., 4, 549-556. https://doi.org/10.12980/APJTB.4.2014APJTB-2013-0039

Kuś, P. M., Jerković, I., Tuberoso, C. I. G., Marijanović, Z., \& Congiu, F. (2014). Cornflower (Centaurea cyanus L.) honey quality parameters: Chromatographic fingerprints, chemical biomarkers, antioxidant capacity and others. Food Chemistry, 142, 12-18. https://doi.org/10.1016/j.foodchem.2013.07.050

Mamary, M. A. Al-Meeri, \& Al-Habori, M. (2002). Antioxidant activities and total phenolics of different types of honey. Nutrition Research, 22(9), 1041-1047. https://doi.org/10.1016/S0271-5317(02)00406-2

Michalkiewicz, A., Biesaga, M., \& Pyrzynska, K. (2008). Solid-phase extraction procedure for determination of phenolic acids and some flavonols in honey. Journal of Chromatography A, 1187(1-2), 18-24. https://doi.org/10.1016/j.chroma.2008.02.001

Martos, I., Ferreres, F., Yao, L., D-Arcy, B., Caffin, N., \& Tomas-Barberan, F. A. (2000). Flavonoids in 
monospecific Eucalyptus honeys from Australia. J. Agric. Food Chem., 48, 4744-4748. https://doi.org/10.1021/jf000277i

McKibben, J., \& Engeseth, N. J. (2002) Honey as a protective agent against lipid oxidation in ground turkey. J. Agric. Food Chem., 50, 592-595. https://doi.org/10.1021/jf010820a

Meda, A., Lamien, C. E., Romito, M., Millogo, J., \& Nacoulma, O. G. (2005). Determination of the total phenolic, flavonoid and proline contents in Burkina Fasan honey, as well as their radical scavenging activity. Food Chemistry, 91(3), 571-577. https://doi.org/10.1016/j.foodchem.2004.10.006

Milojkovic, D., \& Kec, S. (2013). The determination of phenolic profiles of Serbian unifloral honeys using ultra-high-performance liquid chromatography / high resolution accurate mass spectrometry. Food Chemistry, 138, 32-40. https://doi.org/10.1016/j.foodchem.2012.10.025

Moniruzzaman, M., An, C. Y., Rao, P. V., Nurul, M., Hawlader, I., Binti, S. A., \& Gan, S. H. (2014). Identification of Phenolic Acids and Flavonoids in Monofloral Honey from Bangladesh by High Performance Liquid Chromatography: Determination of Antioxidant Capacity. BioMed Research International, Volume 2014, Article ID 737490. https://doi.org/10.1155/2014/737490

Nagai, T., Sakai, M., Inoue, R., Inoue, H., \& Suzuki, N. (2001). Antioxidative activities of some commercially honeys, royal jelly, and propolis. Food Chemistry, 75, 237-240. https://doi.org/10.1016/S0308-8146(01)00193-5

Oelschlaegel, S., Gruner, M., Wang, P. N., Boettcher, A., Koelling-Speer, I., \& Speer, K. (2012). Classification and characterization of manuka honeys based on phenolic compounds and methylglyoxal. Journal of Agricultural and Food Chemistry, 60(29), 7229-7237. https://doi.org/10.1021/jf300888q

Osés, S. M., Pascual-Maté, A., de la Fuente, D., de Pablo, A., Fernández-Muiño, M. A., \& Sancho, M. T. (2016). Comparison of methods to determine antibacterial activity of honeys against Staphylococcus aureus. NJAS Wageningen Journal of Life Sciences, 78, 29-33.Https://doi.org/10.1016/j.njas.2015.12.005

Silici, S., Sagdic, O., \& Ekici, L. (2010). Total phenolic content, antiradical, antioxidant and antimicrobial activities of Rhododendron honeys. Food Chemistry, 121(1), 238-243. https://doi.org/10.1016/j.foodchem.2009.11.078

Soria, A. C., Sanz, J., \& Martínez-Castro, I. (2009). SPME followed by GC-MS: A powerful technique for qualitative analysis of honey volatiles. European Food Research and Technology, 228(4), 579-590. https://doi.org/10.1007/s00217-008-0966-z

Spilioti, E., Jaakkola, M., Tolonen, T., Lipponen, M., Virtanen, V., Chinou, I., \& Moutsatsou, P. (2014). Phenolic acid composition, antiatherogenic and anticancer potential of honeys derived from various regions in Greece. PLoS ONE, 9(4), 1-10. https://doi.org/10.1371/journal.pone.0094860

Sumarlin, L. O., Muawanah, A., \& Wardhani, P. (2014). Aktivitas Antikanker dan Antioksidan Madu di Pasaran Lokal Indonesia ( Anticancer and Antioxidant Activity of Honey in the Market Local Indonesia ). Jurnal Ilmu Pertanian Indonesi (JIPI), 19(3), 136-144.

Tahir, H. E., Xiaobo, Z., Zhihua, L., Jiyong, S., \& Zhai, X. (2017). Rapid prediction of phenolic compounds and antioxidant activity of Sudanese honey using Raman and Fourier transform infrared (FT-IR) spectroscopy. Food Chemistry. https://doi.org/10.1016/j.foodchem.2017.01.024

Tomas-Barberán, F. A., Martos, I., Ferreres, F., Radovic, B. S., \& Anklam, E. (2001). HPLC flavonoid profiles as markers for the botanical origin of European unifloral honeys. J. Sci. Food Agric., 81, 485-496. https://doi.org/10.1002/jsfa.836

Tomas-Barberán, F. A., Martos, I., Ferreres, F., Radovic, B. S., \& Anklam, E. (2001). HPLC flavonoid profiles as markers for the botanical origin of European unifloral honeys. J. Sci Food Agric, 81. https://doi.org/10.1002/jsfa.836

Tomas-Barberan, F. A., Ferreres, F., Garcia-Viguera, C., \& Tomas-Lorente, F (1993). Flavonoids in honey of different geographical origin. Z. Lebensm. Unters. Forsch. 196, 38-44. https://doi.org/10.1007/BF01192982

Yaoa, L., Jiang, Y., Singanusong, R., Datta, N., \& Raymont, K. (2005). Phenolic acids in Australian Melaleuca, Guioa, Laphostemon, Banksia and Helianthus honeys and their potential for floral authentication. Food Res. Internat., 38, 651-658. https://doi.org/10.1016/j.foodres.2005.01.002

Pyrzynska, K., \& Biesaga, M. (2009). Analysis of phenolic acids and flavonoids in honey. TrAC - Trends in Analytical Chemistry, 28(7), 893-902. https://doi.org/10.1016/j.trac.2009.03.015 
Tomaand́s-Barberaand́n, F. A., Martos, I., Ferreres, F., Radovic, B. S., \& Anklam, E. (2001). HPLC flavonoid profiles as markers for the botanical origin of European unifloral honeys. Journal of the Science of Food and Agriculture, 81(5), 485-496. https://doi.org/10.1002/jsfa.836

Yao, L., Jiang, Y., D’Arcy, B., Singanusong, R., Datta, N., Caffin, N., \& Raymont, K. (2004). Quantitative High-Performance Liquid Chromatography Analyses of Flavonoids in Australian Eucalyptus Honeys. Journal of Agricultural and Food Chemistry, 52(2), 210-214. https://doi.org/10.1021/jf034990u

Zhao, J., Du, X., Cheng, N., Chen, L., Xue, X., Zhao, J., Wu, L., \& Cao, W. (2016). Identification of monofloral honeys using HPLC-ECD and chemometrics. Food Chemistry, 194, 167-174. https://doi.org/10.1016/j.foodchem.2015.08.010

Zhishen, J., Mengcheng, T., \& Jianming, W. (1990). The determination of flavonoid contents in mulberry and their scavenging effects on superoxide radicals. Food Chemistry, 64(4), 555-559.

https://doi.org/10.1016/S0308-8146(98)00102-2

\section{Copyrights}

Copyright for this article is retained by the author(s), with first publication rights granted to the journal.

This is an open-access article distributed under the terms and conditions of the Creative Commons Attribution license (http://creativecommons.org/licenses/by/4.0/). 